\title{
Transformation and digital literacy: Systematic literature mapping
}

\author{
Silvia Farias-Gaytan ${ }^{1}$ (1) Ignacio Aguaded ${ }^{2}$ (1) . \\ Maria-Soledad Ramirez-Montoya ${ }^{3}$ (1)
}

Received: 26 March 2021 / Accepted: 7 June 2021 / Published online: 15 July 2021

(c) The Author(s) 2021

\begin{abstract}
The advancements of technology have allowed digital transformation to reach all productive sectors, including the education sector and its members. This transformation is linked to emerging technologies, the digitalization of processes and resources, and the demand for users to upgrade to the latest technological updates. This research aims to analyze digital transformation and media literacy publications that impact higher education. Its purpose is to identify the types of research and topics they address and explore the scope of digital transformation in higher education institutions. The systematic mapping method was used to analyze 298 articles published in two databases, Scopus and Web of Science (WoS). Inclusion and exclusion criteria were applied to select the articles that could be included in this research. The results show that the largest proportion of articles were found in Scopus, and used both qualitative and quantitative empirical research methods, followed by theoretical-conceptual methods and, to a lesser extent, mixed methods. Likewise, the publications originated in five continents, and the Journal of Adolescent and Adult Literacy had the largest number of publications, with 14. Forty-two percent of the studies were classified in the strategy category, with the most mentioned topic being digital pedagogies. This research provides a perspective on digital transformation studies in higher education institutions and their internalization approaches. This research may be of value to trainers, students, decision-makers, and researchers interested in transformation, educommunication, and educational innovation.
\end{abstract}

Keywords Digital transformation · Media literacy $\cdot$ Higher education · Educational innovation $\cdot$ Systematic mapping $\cdot$ Educommunication

Silvia Farias-Gaytan

silvia.farias@tec.mx; silviacatalian.farias@alu.uhu.es

Extended author information available on the last page of the article 


\section{Introduction}

The development of technologies accelerated with the introduction and growth of the internet during the last century. During the last decade of the twentieth century, the internet facilitated companies to reach more users within and beyond their territories. Since the beginning of the twenty-first century, social networks and mobile devices have changed how we communicate with each other (Schallmo et al., 2017). Companies committed to developing their information systems and digitalizing their processes have produced the current digital transformation (Osmundsen, 2020; Vial, 2019). This digital transformation is understood as the formation of networks of actors, such as companies and customers, in all value chain segments and the application of new technologies (Schallmo et al., 2017). However, digital transformation goes beyond just the use of technology; it must consider changes in talent, culture, and organizational structure. (Kane et al., 2017) (see Table 1). Both the public and private sectors have adopted technological advances, although not all have done so in the same way. Nevertheless, this has boosted their development (Jackson, 2019; Pihir et al., 2019). Even the education sector has not been left out of this transformation.

Universities have embarked on the road to digital transformation and have incorporated technologies in their educational, administrative, and communication processes. Advances such as educational technology platforms and electronic communications such as email and social media messaging (Sjöberg \& Lilja, 2019) are used regularly in the university. Both teachers and students have access to these technologies and digital resources, which has been a catalyst for universities to reassess their traditional education models. (Bond et al., 2018; Jackson, 2019). Moreover, to drive and ensure the university's digital transformation, it is necessary to develop both the teachers' and students' skills (Bond et al., 2018; Khitskov et al., 2017) to adapt and use advanced technology. Technological changes have caused users to learn and unlearn, develop new competencies, be spectators, and even contribute content.

Table 1 Digital transformation categories (Anderson \& Ellerby, 2018)

\begin{tabular}{|c|c|}
\hline Category & Description \\
\hline Customer & $\begin{array}{l}\text { Providing an experience where customers view the organization as their digital } \\
\text { partner using their preferred channels of interaction to control their connected } \\
\text { future on and offline }\end{array}$ \\
\hline Strategy & $\begin{array}{l}\text { Focuses on how the business transforms or operates to increase its competi- } \\
\text { tive advantage through digital initiatives; it is embedded within the overall } \\
\text { business strategy }\end{array}$ \\
\hline Technology & $\begin{array}{l}\text { Underpins digital strategy's success by creating, processing, storing, secur- } \\
\text { ing, and exchanging data to meet the customers' needs at low cost and low } \\
\text { overheads }\end{array}$ \\
\hline Operations & $\begin{array}{l}\text { Executing and evolving processes and tasks by utilizing digital technologies to } \\
\text { drive strategic management and enhance business efficiency and effectiveness }\end{array}$ \\
\hline Organization \& Culture & $\begin{array}{l}\text { Defining and developing an organizational culture with governance and talent } \\
\text { processes to support progress along the digital maturity curve and flexibly } \\
\text { achieve growth and innovation objectives }\end{array}$ \\
\hline
\end{tabular}


Users of technology must acquire the knowledge and skills to use it effectively for their learning. One of the challenges is that users must dedicate time to develop new skills to operate and apply the technology (Fucili et al., 2020; Mendieta Baltodano, 2016; Salmieri, 2019). The classroom's digital transformation goes beyond the use of tools and software; it impacts the knowledge and skills of its users, teachers, and students, and the didactics and processes of educational institutions (Fucili et al., 2020; Mendieta Baltodano, 2016; Salmieri, 2019). Examples of using educational technology can be found in digital pedagogies, technology models, and adaptive, open, smart, and disruptive technologies (González-Pérez et al., 2019). Members of educational institutions must be attentive and prepared to keep abreast of the changes brought about by digital transformation.

The skills required for education and work have been subject to change along with technologies. Digital literacy emerged concurrently with the internet's evolution and required knowing how to access, search, and critically analyze information (Liu et al., 2020). With the advent of social networks such as YouTube and Pinterest and access to mobile devices, users have developed new skills to generate digital resources, characterizing media literacy (Koc \& Barut, 2016; Liu et al., 2020). As technology continually evolves, the new skills will not remain static but will continuously change (UNESCO, 2017) (see Table 2). The challenge remains for institutions and individuals to identify, adapt, and adopt the advances to their contextual needs.

Other studies related to digital literacy have provided considerations for mappings. Among the studies is Juergens (2020), highlighting when geospatial data literacy is essential to judge spatial data reliability, contributing to ingenious and reliable thematic maps. Likewise, Da Silva and Cardoso (2020) focused their study on Librarianship and Education, where they highlighted the current social demand for this sector to support lifelong learning in the context of accelerating technological progress. While this research considered the previous contributions, it also sought to analyze publications on digital transformation and media literacy that impacted higher education in 2015-2020 to identify the types of research and topics they

Table 2 Specific emerging issues in the use of educational technology (González-Pérez et al., 2019)

\section{Categories}

- Digital pedagogies: adapting pedagogical and technological resources to each area of knowledge. An example is b-learning, an environment with multimedia technologies

- Technology models: integrating innovation models with technology, such as smart innovation systems, research-based design

- Adaptive technologies: introduce new e-learning systems that adapt to the new needs of society; foster adaptive learning and educational systems (e.g., e-portfolios and Web 2.0)

- Open technologies: enable open access for the dissemination of open knowledge, including open platforms, repositories, open resources, MOOCs, and open science

- Smart technologies: use smart tools and devices, such as Big Data, data mining, data analytics, cloud technologies, cloud computing in educational contexts, m-learning

- Disruptive technologies: involve new processes and services with leapfrog technologies, such as augmented reality, sensory stimulation, abstract imagery, virtual and remote laboratories 
addressed and provide data for educommunication. A systematic mapping of articles published in 2015-2020 was performed to carry out the above. This document presents the methodology, results, discussion, and limitations of the research, and it closes with a discussion of digital literacy trends to contribute to educommunication.

\section{Research questions}

This study investigated the types of research published on the topic of digital transformation and media literacy. The following research questions were defined to obtain timely information on the topic:

- RQ1: How many studies are in the Scopus and WoS databases between 2015 and 2020 , and what is their design?

- RQ2: What are the most cited articles?

- RQ3: What is the geographical distribution of the authors?

- RQ4: Which are the journals with the largest publications on this topic?

- RQ5: How are digital transformation studies classified?

- RQ6: What are the trends and topics addressed by the articles?

\section{Method}

The method applied in this research was systematic literature mapping, which provides the means to identify, evaluate, and interpret the published literature available on a study topic. (García-Peñalvo, 2017; Kitchenham \& Charters, 2007). The protocol applied to analyze the articles, as shown in Fig. 1, consisted of five phases (Ramírez-Montoya \& Lugo-Ocando, 2020).

\subsection{Definition of research questions}

During phase 1, six questions were established to analyze the research published over five years (2015-2020). The questions were designed to cover the research's objective and identify relevant and specific characteristics that could answer the questions shown in Table 3 (García-Peñalvo, 2017; Kitchenham \& Charters, 2007).

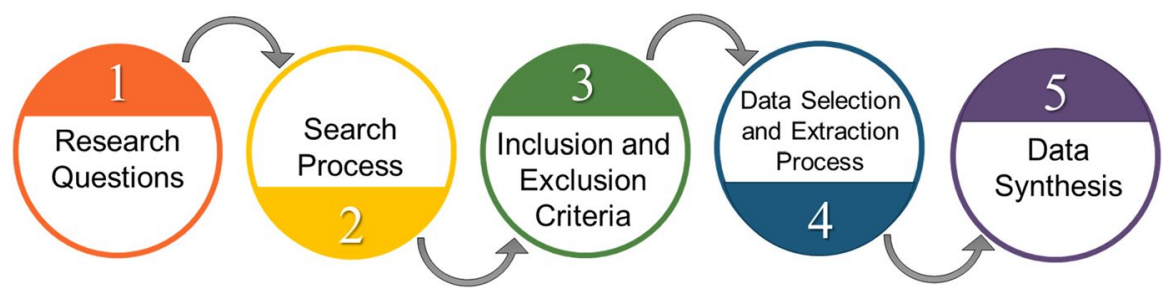

Fig. 1 Protocol for the analysis of methodological mapping 
Table 3 Research questions (self-elaborated)

\begin{tabular}{|c|c|}
\hline Research Question & Type of Answer sought \\
\hline $\begin{array}{l}\text { RQ1: How many studies are in the Scopus and Web of Science } \\
\text { databases between } 2015 \text { and } 2020 \text {, and what is their design? }\end{array}$ & $\begin{array}{l}\text { No. of articles in Scopus } \\
\text { No. of articles in Web of Science } \\
\text { No. of theoretical-conceptual articles } \\
\text { No. of empirical research articles } \\
\text { No. of mixed methods articles }\end{array}$ \\
\hline RQ2: What are the most cited articles? & Most cited articles \\
\hline RQ3: What is the geographical distribution of the authors? & Countries of the first authors \\
\hline $\begin{array}{l}\text { RQ4: Which are the journals with the largest publications on this } \\
\text { topic? }\end{array}$ & $\begin{array}{l}\text { Q1, Q2, Q3 or Q4, ESCI, No rank } \\
\text { Open Access }\end{array}$ \\
\hline RQ5: How are digital transformation studies classified? & $\begin{array}{l}\text { Customer } \\
\text { Strategy } \\
\text { Technology } \\
\text { Operations } \\
\text { Organization and culture }\end{array}$ \\
\hline RQ6: What are the trends and topics addressed by the articles? & $\begin{array}{l}\text { Technology models } \\
\text { Digital pedagogies } \\
\text { Open technologies } \\
\text { Adaptive technologies } \\
\text { Disruptive technologies } \\
\text { Intelligent technologies }\end{array}$ \\
\hline
\end{tabular}

In particular, the questions emanated from the interest in integrating the subject in aspects of education, innovation, and educommunication to provide data that can be of value for training and research processes. Table 3 lists the research questions, and the type of answer sought.

\subsection{Search process}

In phase 2, the search process considered the Scopus and Web of Science (WoS) databases, which cover many publications, the thematic areas, and the selected range of years (Mongeon \& Paul-Hus, 2016). In the strings' construction, the Boolean operators, AND and OR, were used to integrate the selected variables. An iterative process with several tests was carried out to obtain the highest number of results in both databases (Kitchenham \& Charters, 2007; Vial, 2019). Table 4 shows the strings and search terms applied on October 23, 2020.

\subsection{Inclusion and Exclusion Criteria}

In phase 3 , the inclusion and exclusion of publications criteria were defined considering they were indexed in the selected databases, related to the subject matter, and in the range from years 2015 to 2020. Those that did not meet the inclusion criteria were excluded. Also, papers and articles of previous access or review and those in publications not of high impact were discarded. Likewise, the 
Table 4 Search strings in Scopus and WoS

\begin{tabular}{ll}
\hline Search strings in Scopus & Search strings in WoS \\
\hline (TITLE-ABS-KEY (("digital transformation" OR & TOPIC: (("digital transformation" OR "digital*")) \\
"digital*")) AND TITLE-ABS-KEY ( ( "univer- & AND TOPIC: (( "university" OR "higher educa- \\
sity" OR "higher education" OR "tertiary educa- & tion" OR "tertiary education")) AND TOPIC: (( \\
tion")) AND TITLE-ABS-KEY ( ( "model" OR & "model" OR "framework" OR "system")) AND \\
"framework" OR "system")) AND TITLE-ABS- & TOPIC: (( "media literacy" OR "digital compe- \\
KEY ( ( "media literacy" OR "digital compe- & tenc*" OR "digital literacy")) \\
tenc*" OR "digital literacy"))) AND DOCTYPE ( & \\
ar) AND PUBYEAR> 2014 & \\
\hline
\end{tabular}

publications' language was limited to English and Spanish because these are the languages in which the researchers are fluent. The inclusion and exclusion criteria are presented in Table 5.

\subsection{Selection Process and Data Extraction}

In phase 4, the articles were searched, then data extraction was performed, and then the information was input into an Excel database. The search resulted in 374 articles: 231 in Scopus and 143 in WoS. The information extracted from each article included the author(s), keywords, title, type of access, year of publication, name of publication source, number of citations, DOI number, affiliations, language, country, and abstract. Based on these data, 76 duplicate articles were identified and moved to another sheet of the database, resulting in 298 articles as review candidates.

The missing information for each entry was then completed. Regarding the impact factor, 241 were found with an impact factor in Scopus and WoS, 46 in the Emerging Sources Citation Index (ESCI), and 11 with no rank. Figure 2 structures the delimitation based on the PRISMA method (Moher et al., 2009).

Table 5 Inclusion and Exclusion Criteria (own elaboration)

\begin{tabular}{|c|c|}
\hline Inclusion criteria & Exclusion criteria \\
\hline Studies indexed in the Scopus and WoS databases & Studies that do not address digital transformation \\
\hline $\begin{array}{l}\text { Studies on digital transformation and media } \\
\text { literacy }\end{array}$ & Proceedings, papers or early access or review \\
\hline Scientific articles & $\begin{array}{l}\text { Articles that have not been published in high-impact } \\
\text { journals }\end{array}$ \\
\hline \multicolumn{2}{|l|}{ Articles published in high-impact journals } \\
\hline Articles published during 2015-2020 & Articles not published during 2015-2020 \\
\hline Articles on studies related to Higher Education & $\begin{array}{l}\text { Articles published in Russian, German, Malay, } \\
\text { Portuguese, Hungarian, Ukrainian }\end{array}$ \\
\hline $\begin{array}{l}\text { Articles on studies related to frameworks propos- } \\
\text { als }\end{array}$ & \\
\hline
\end{tabular}



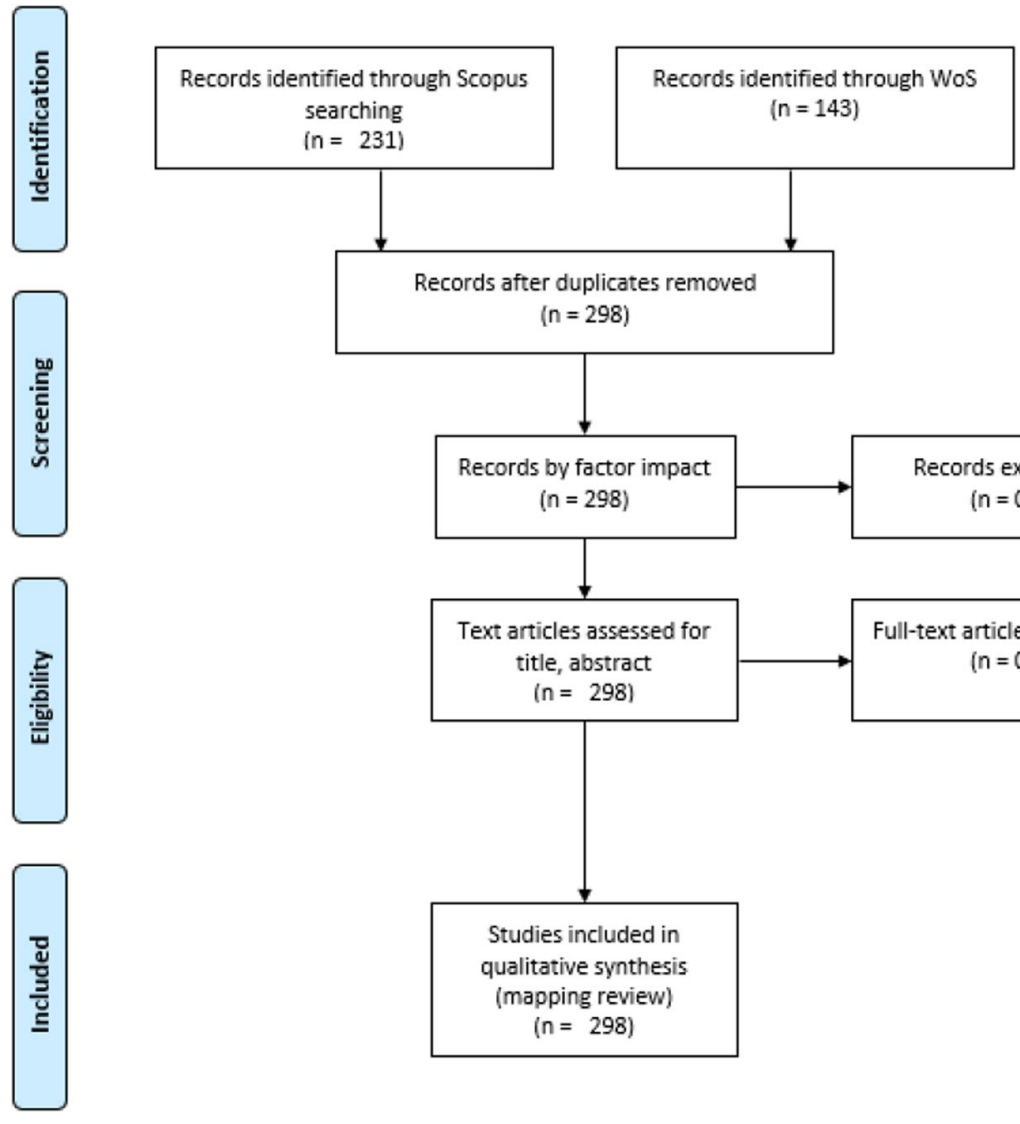

Records after duplicates removed

( $n=298$ )

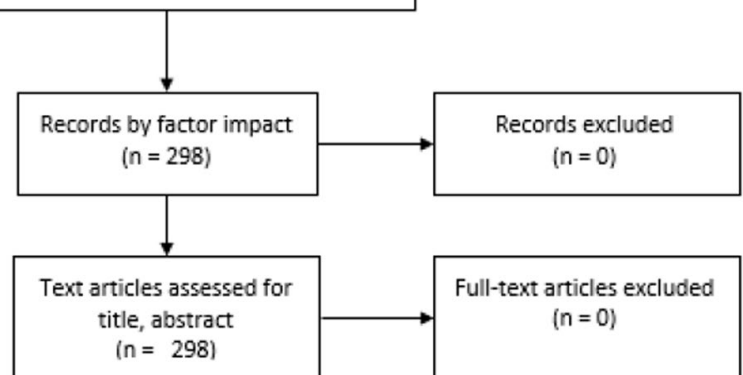

Fig. 2 Selection Process

Studies included in

qualitative synthesis

(mapping review)

( $n=298$ )

\subsection{Data Synthesis}

In phase 5, a classification was sought in the digital transformation subject to answer question RQ5, and the Digital Maturity Model (Anderson \& Ellerby, 2018) focused on organizations was selected. Those categories are included in Table 1. The abstract's information, the keywords, and the article's title were reviewed to categorize each article.

\section{Results}

The systematic literature mapping methodology results documented in an Excel database were available at the following address: https://doi.org/10.6084/m9.figsh are. 14151563. 
In this database, the information was organized to answer each research question.

\subsection{RQ1 How many studies are in the Scopus and WOS databases between 2015 and 2020 , and what is their design?}

The number of articles that met the inclusion and exclusion criteria was $298 ; 77.5 \%$ were found in the Scopus database. Figure 3 shows $51.7 \%$ of the empirical research studies, which used qualitative research (MacLure \& Stewart, 2018; Wang et al., 2017), in-depth interviews (Önger \& Çetin, 2018; Poncette et al., 2019; Suwana \& Lily, 2017), or quantitative research. The latter was surveys applied to groups of students or teachers to approach the subject through case studies (Amhag et al., 2019; Colás-Bravo et al., 2017; Khan \& Bhatti, 2017; Miralles-Martínez et al., 2019; Munoz-Repiso \& del Pozo, 2016; NIH Office of Behavioral \& Social Sciences Research, 2018; Sánchez et al., 2017). Few studies used mixed methods; some opted to apply surveys and documentary or case studies (Tømte et al., 2015; TorresCoronas \& Vidal-Blasco, 2015; Villarreal-Villa et al., 2019).

\subsection{RQ2 What are the most cited articles?}

Analysis of the data showed one article had the highest number of citations (59) (Cronin, 2017). The article focuses on open education practices and the development of digital literacy. The second had 40 citations, (Murray \& Pérez, 2015) which addresses adaptive learning issues and their impact on learning outcomes. Article

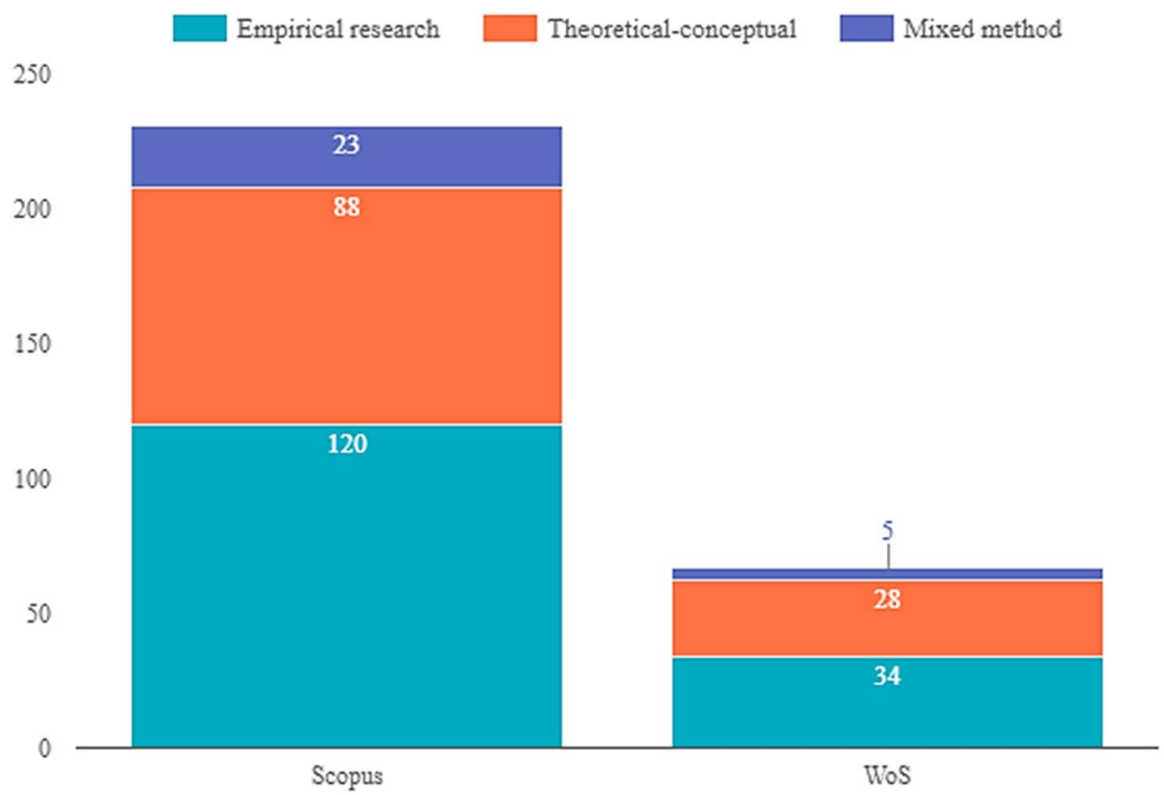

Fig. 3 Number of articles by type of study 
Table 6 Articles with the highest number of citations (own elaboration)

\begin{tabular}{|c|c|}
\hline $\begin{array}{l}\text { Number } \\
\text { of cita- } \\
\text { tions }\end{array}$ & Identification number of the cited articles \\
\hline 59 & 255 \\
\hline 40 & 296 \\
\hline 39 & 291 \\
\hline 34 & 287 \\
\hline 31 & 208 \\
\hline 26 & 193,277 \\
\hline 25 & 250 \\
\hline 24 & 271,290 \\
\hline 22 & 292 \\
\hline 20 & 294 \\
\hline 18 & $195,266,293$ \\
\hline 17 & $142,246,281$ \\
\hline 16 & 136 \\
\hline 15 & 210 \\
\hline 14 & $217,249,278$ \\
\hline 13 & 283 \\
\hline 12 & 253,274 \\
\hline 11 & $33,183,265,268$ \\
\hline 10 & $192,207,211,222,227,256$ \\
\hline 9 & $165,173,203,223,240$ \\
\hline 8 & $8,40,137,189,235,238,248,264$ \\
\hline 7 & $112,114,251,280,285,295$ \\
\hline 6 & $157,191,214,245,252,259,279,288$ \\
\hline 5 & $54,117,126,148,166,167,186,194,215,270,272,282$ \\
\hline 4 & $34,70,161,205,220,236,269,289$ \\
\hline 3 & $\begin{array}{l}\text { 48, } 121,122,124,134,140,144,146,147,159,164,196,202,204,216,231,233,257,267 \text {, } \\
275\end{array}$ \\
\hline 2 & $\begin{array}{l}13,22,23,31,37,46,50,74,79,106,113,119,130,145,153,163,171,181,184,185,197, \\
199,209,213,226,228,232,234,239,241,247,258,260,284\end{array}$ \\
\hline 1 & $\begin{array}{l}4,18,19,39,47,62,66,83,96,102,110,111,115,123,125,128,132,133,135,138,139 \\
141,143,151,152,154,156,158,160,169,170,172,176,178,180,188,190,198,212 \\
218,219,224,263,276,298\end{array}$ \\
\hline 0 & $\begin{array}{l}1,2,3,5,6,7,9,10,11,12,14,15,16,17,20,21,24,25,26,27,28,29,30,32,35,36,38 \\
\quad 41,42,43,44,45,49,51,52,53,55,56,57,58,59,60,61,63,64,65,67,68,69,71,72 \\
\quad 73,75,76,77,78,80,81,82,84,85,9\end{array}$ \\
\hline
\end{tabular}

with 39 citations (Tømte et al., 2015) contributes to the study of online programs for teachers and digital competencies (see Table 6).

The topics of digital transformation and media literacy in higher education have shown interest since 2015. In 2019 and 2020, publications increased 23\% and 50\% over the previous year (see Fig. 4). 


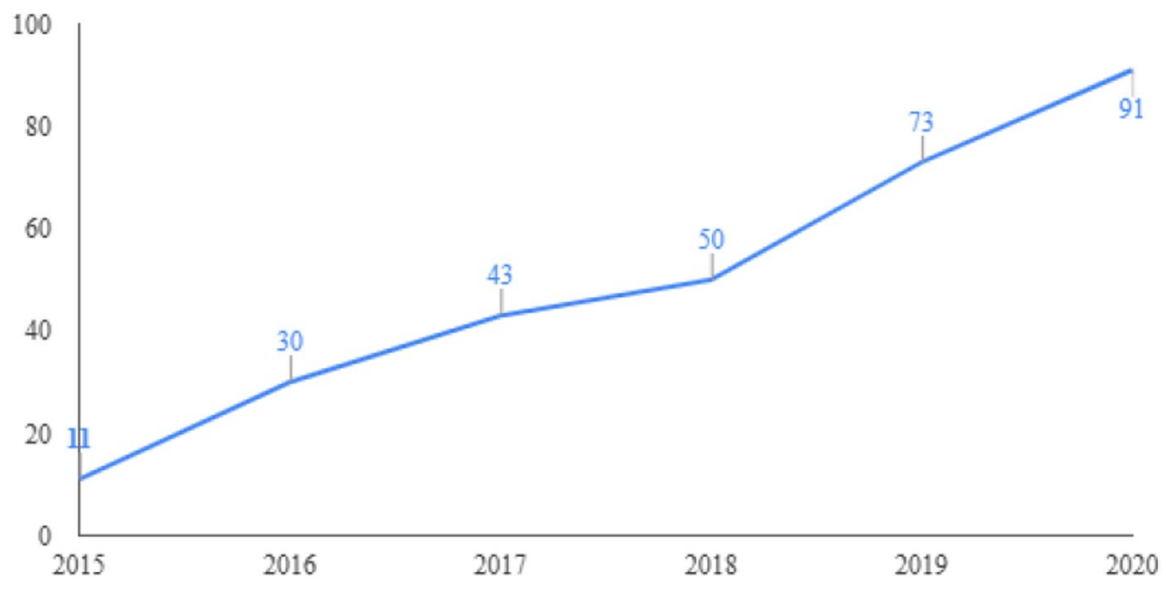

Fig. 4 Number of publications per year

\subsection{R3. What is the geographical distribution of the authors?}

The first author's country of origin was used to identify the publication's geographical distribution. The authors' presence was found in 59 countries in five continents, evidencing the international research work on digital transformation and media literacy (Fig. 5). Five countries accounted for 52\% of the authors: Spain, the United States, the United Kingdom, Australia, and Russia (Fig. 6). This data can be of value to locate researchers, networks, and institutions working on this topic to seek collaborations.

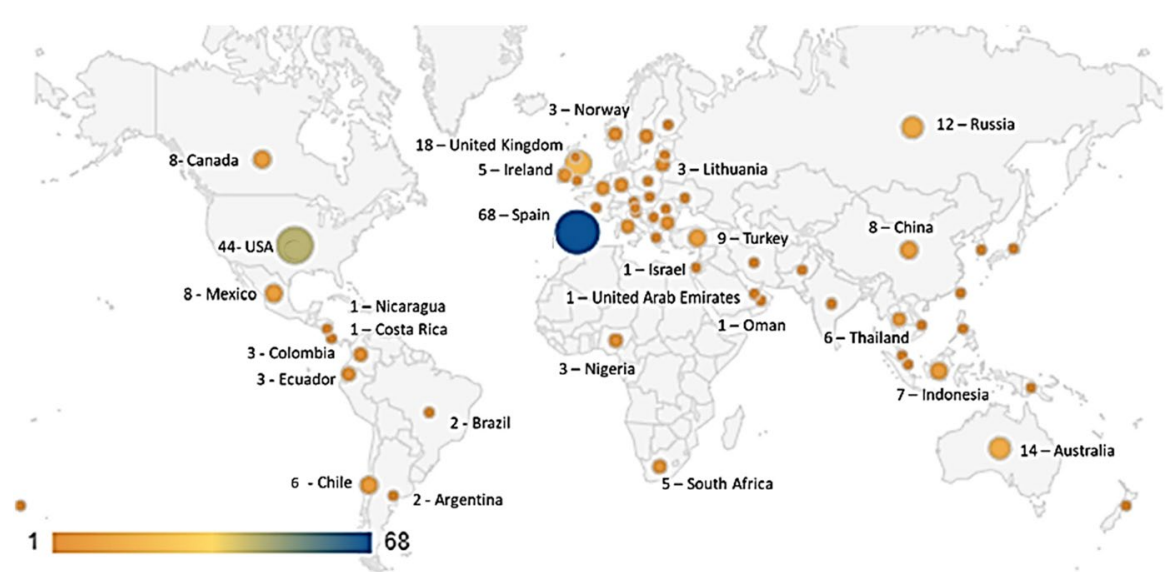

Fig. 5 Geographical distribution of authors 


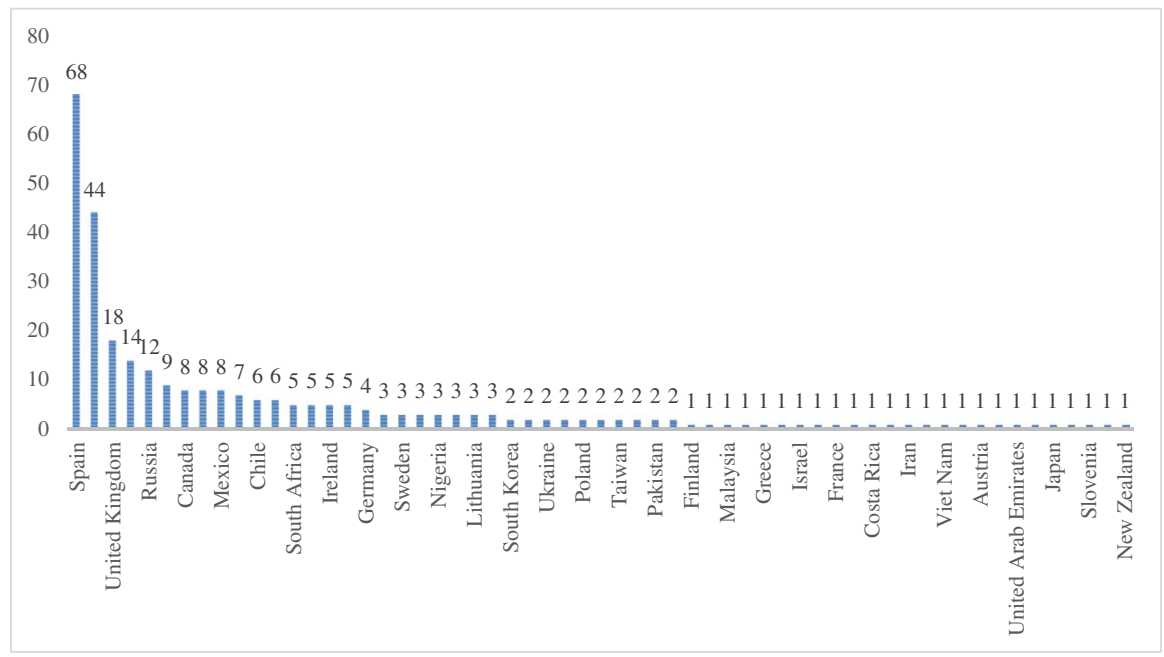

Fig. 6 Frequency of publications by country

\subsection{RQ4: Which are the journals with the most publications on this subject?}

The journals with the highest number of articles published on digital transformation and media literacy are shown in Table 7. Twenty-one journals with at least three articles were identified. The Journal of Adolescent and Adult Literacy stands out with 14 articles. $81 \%$ of the articles published were in journals with an impact factor. Of those articles, $48 \%$ were Q1 and Q2, and 19\% were published in ESCI journals and without identified rank (see Table 8). This data may be of interest to support theoretical and conceptual frameworks on the subject, analyze different contextual practices, or make studies visible.

\subsection{RQ5: How are digital transformation studies classified?}

Nearly half of the publications (42\%) focused on innovation issues associated with business strategy, including incorporating new learning practice designs (Ting, 2015). 26\% were research studies on teaching staff training (Creswell, 2014; Cronin, 2017; Tømte et al., 2015) classified in organization and culture, and $27 \%$ referred to the student's experience (Bond et al., 2018) in the customer category. The remaining 5\% was made up of the category of technology in mobile learning (Bates et al., 2017) and operations with new processes (Wanotayapitak et al., 2019) (see Fig. 7).

\subsection{RQ6: What are the trends and issues addressed in the articles?}

Most of the studies (75\%) referred to pedagogies that evaluate digital transformation elements and their impact on users' digital skills. $18 \%$ were conducted on 


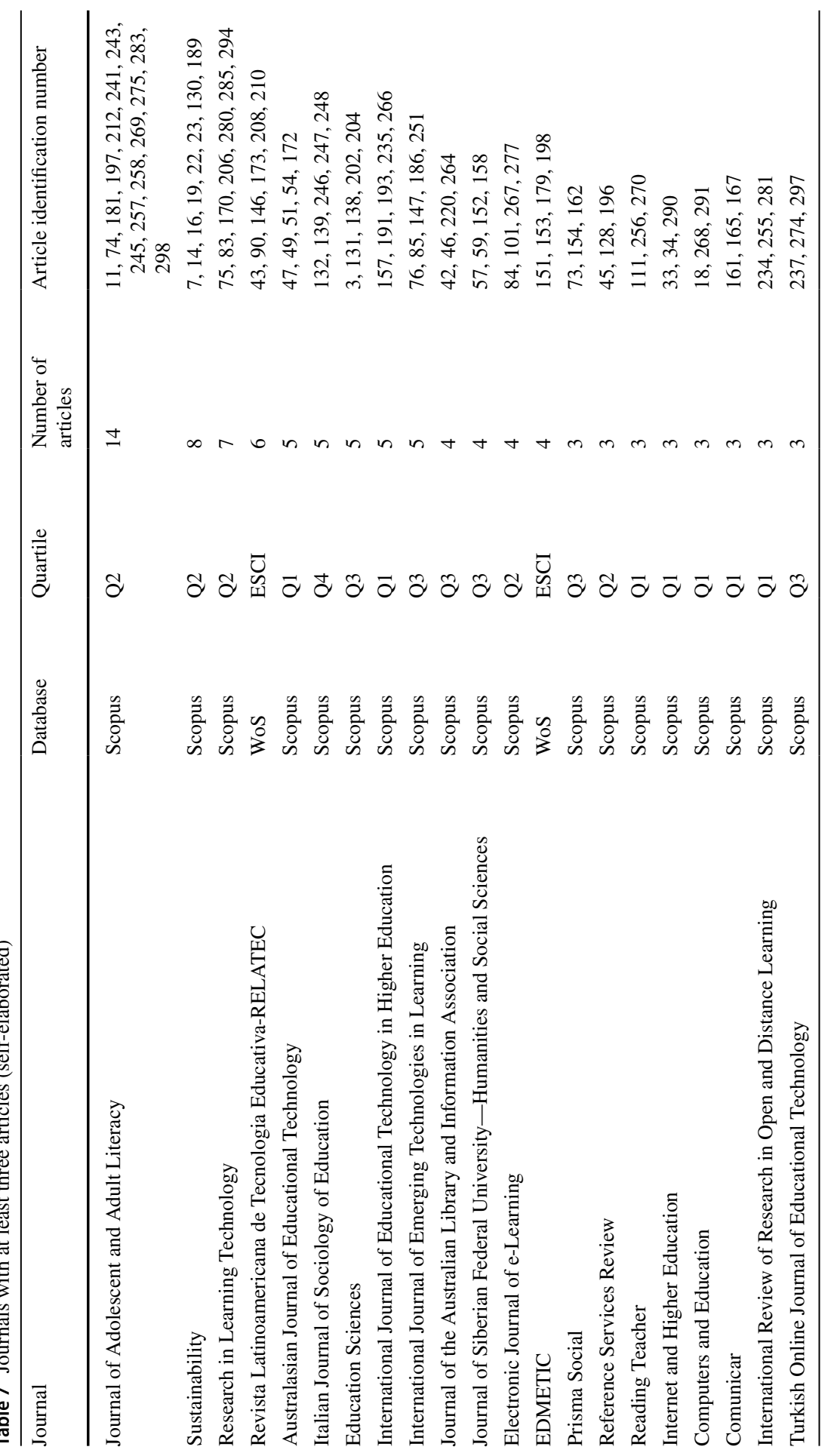




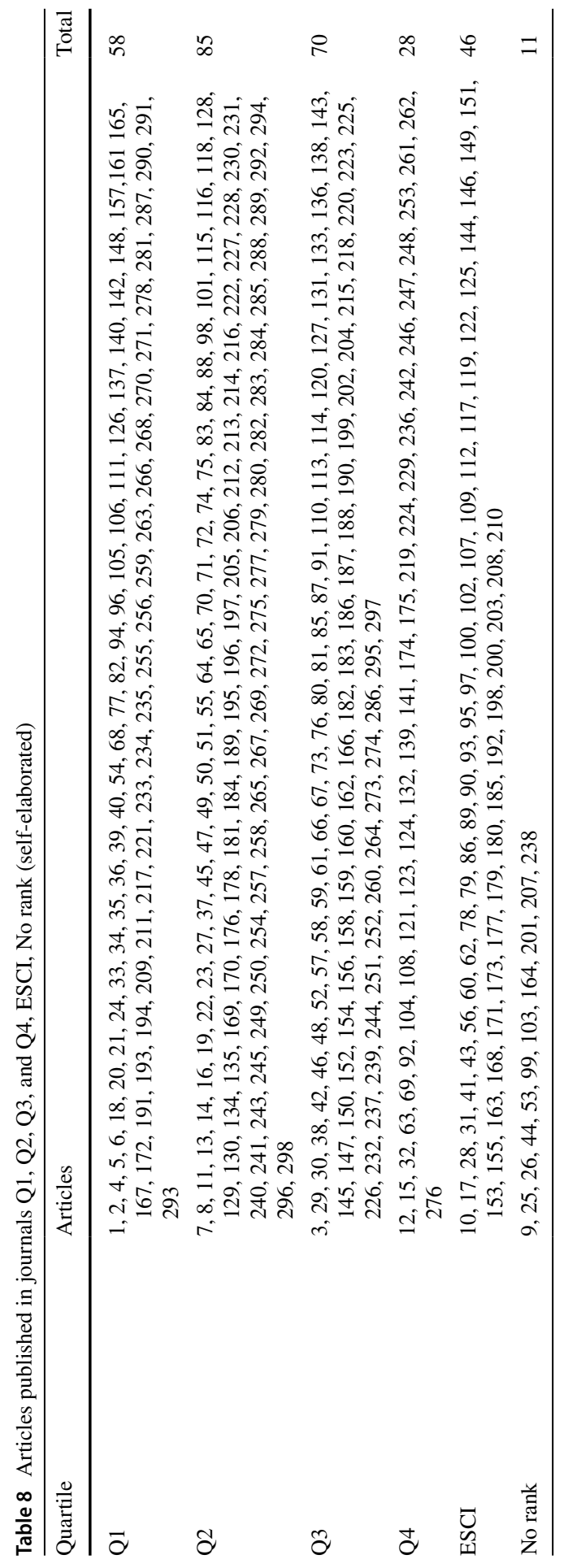




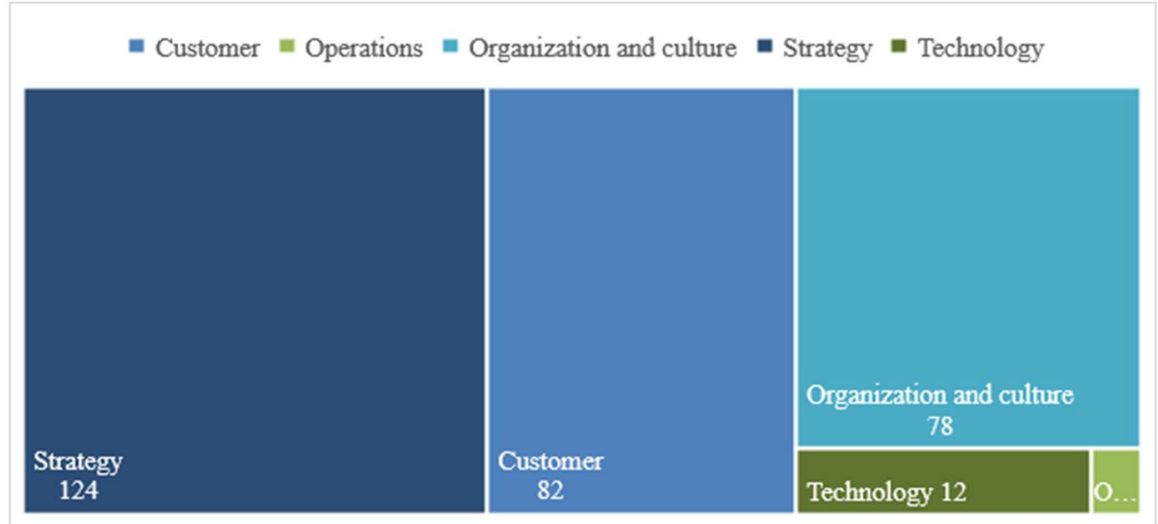

Fig. 7 Classification of digital transformation studies

using adaptive technologies that "adapt to society's needs and promote learning" (González-Pérez et al., 2019, p. 24), such as the use of Web 2.0 resources and applications (Guillén-Gámez et al., 2020). Open technologies, which "enable open access for the dissemination of knowledge" (González-Pérez et al., 2019, p.24) include open education practices (Cronin, 2017). Others are smart technologies that use mobile learning (Bates et al., 2017) or disruptive technologies that "involve new processes or services that generate structural or functional changes" (GonzálezPérez et al., 2019, p. 24). These include the use of extended reality in education (see Fig. 8). Technological models is another category referred as "those that integrate innovation models with technology, such as smart innovation system, researchbased design" (González-Pérez et al., 2019, p.24) and include geo-spatial referencing (Appel, 2019). The interest in applying trends in education is evidenced by the diversity of studies conducted during 2015-2020.

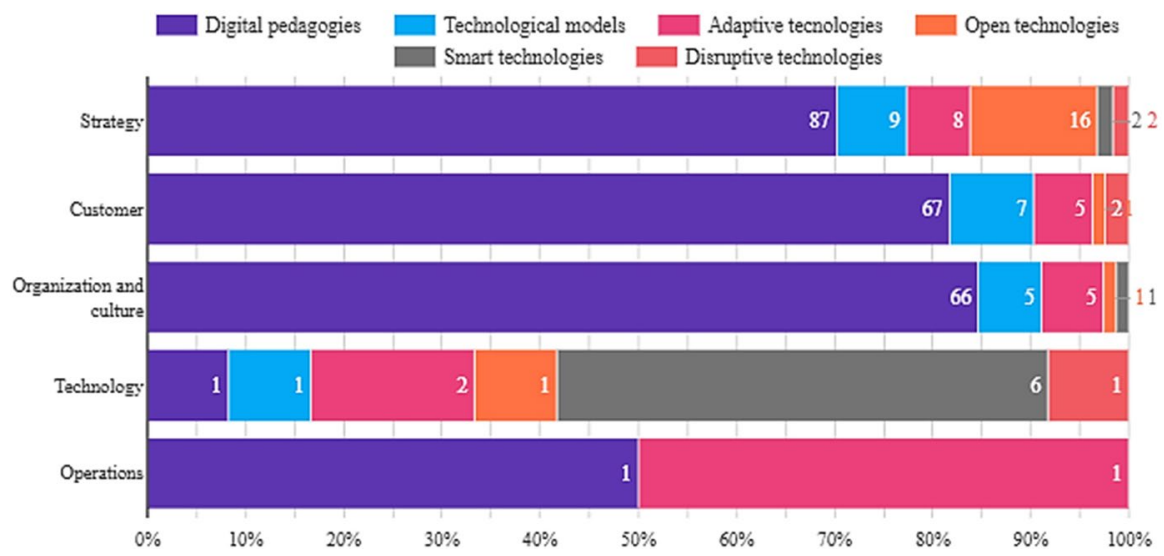

Fig. 8 Trends and issues addressed by the articles 


\section{Discussion}

Scientific production on digital transformation and media literacy in the context of higher education institutions is a topic of interest among researchers. The results of this study indicated that empirical and conceptual-theoretical studies predominate over mixed studies, and that the Scopus database contains the largest number of articles (Fig. 3). The search strategy for systematic reviews requires defining the primary sources of information appropriate to the object of study (Kitchenham \& Charters, 2007); moreover, the identification of methodological approaches guides researchers in taking up or exploring new studies (RamírezMontoya \& Lugo-Ocando, 2020). Formal research provides the basis for results that support decision-making in teaching practice, as well as in the strategy of educational institutions.

Digital transformation and its impact on media literacy are topics of interest for higher education institutions, both for its influence on learning processes and on the operation of the institution. In this research, the interest is evident in the increase of publications in the last five years (Table 6), as well as in the citations of the articles (Fig. 4), with the topics of the three most cited articles being digital literacy, adaptive learning, and digital competencies of teachers (Fig. 5). The adoption of new technologies in higher education ranges from electronic means of communication to platforms for delivery of learning resources, as well as systems that advance administrative processes (Sjöberg \& Lilja, 2019), this demands that teachers and students develop new competencies to also evolve the teaching-learning process and be prepared for the demands of the work environment (Jackson, 2019). Technology works as the engine of innovation; its advances and new proposals, adapted to each context, generate new knowledge to learn, as well as new ways of learning.

In the last five years, publications on transformation and digital literacy experiences demonstrated a steady increase in several countries. The results showed the geographical distribution of papers in five continents (Fig. 5), which represents an opportunity to establish networks among researchers, so that the lessons learned from the most experienced can contribute to the development of countries that are just starting out. The country with the most publications was Spain, followed by the United States, the United Kingdom, Australia, and Russia (Fig. 6). International initiatives such as the "Working Group on education: Digital skills for life and work" provide the current state of the UN member countries, as well as the challenges to be met in order to make effective use of digital technologies in the classroom and in the workplace (UNESCO, 2017). Countries and higher education institutions must incorporate new technologies into their strategies and prepare for the changes that these technologies imply in processes, business models and the development of user skills.

Dissemination of research findings provides an opportunity for society to learn from the experiences of others. This study found publications that have incorporated digital transformation and literacy into their subject matter and have published up to 14 articles (Tables 7 and 8); the journals are in the Q1, Q2 and 
Q3 quartiles, and in ESCI journals both in the Scopus database and in Web of Science. Scientific rigor and adherence to guidelines and standards facilitate the replicability of studies; it is important to select specialized databases, as well as journals and papers that have processes to ensure the quality of the studies (Kitchenham \& Charters, 2007). Higher education institutions are considered the traditional sources of knowledge, and it is therefore important that they make it available to society.

Digital transformation has shown a systemic reach in organizations, mainly in key areas over the last five years. Most of the publications reviewed focused on strategy, customer, and organizational and cultural issues (Fig. 7), which in relation to a higher education institution are associated to innovation in learning practices, student experience in mastering digital competencies, and faculty digital competency training, respectively; to a lesser extent, studies were found on technologies and processes (Fig. 8). The development of digital competencies of both teachers and students contributes to the adoption of new technologies that support the learning process (Blau et al., 2020; Bond et al., 2018; Mendieta Baltodano, 2016; Reyna \& Meier, 2018); in addition, educational institutions must generate strategies that ensure a systemic digital transformation so that their services and processes evolve at the same pace (Salmieri, 2019). The incorporation of technologies must be accompanied by strategies that favor their adoption by users and employees, the adaptation of processes and operations, as well as the incorporation of innovation practices on a permanent basis.

Technologies adapted to the educational context enable diverse alternatives that demand and promote the development of digital literacy. The results show trends that are grouped into six categories (Fig. 8), where digital pedagogies that assess elements of digital transformation and their impact on the digital competencies of students and teachers stand out over the other categories. The incorporation of devices, as well as new forms of interaction moved organizations to rethink their processes and incorporate them to adapt to change (Schallmo et al., 2017); as a result, educational institutions have recognized the opportunity provided by technologies and today they are part of most classrooms and educational programs. (Bucea-Manea-Ţoniş et al., 2020; Liu et al., 2020). Even so, it is important to keep in mind that technologies are a means to support the learning process, teachers must define the best way to incorporate them in their classes so that students are prepared for the changing work environment.

\section{Limitations}

This study analyzes trends and innovations associated with various emerging technologies in a specific period. It can serve as a reference and starting point for further research. The mapping was done using two indexing systems (Scopus and Web of Science), so future research can expand to other systems and digital databases. 


\section{Conclusions}

Digital transformation has become a constant, opening numerous possibilities to enrich the educational experience. This research presents trends in digital transformation and digital literacy studies in higher education institutions, and it has even become a topic of interest for governments (Khitskov et al., 2017; Rampelt et al., 2019; Vasilev et al., 2020; Xiao, 2020). As demonstrated in this literature review, educational institutions have adopted digital transformation in various areas of their businesses, including education and services to students, the adoption or creation of new technological applications, and initiatives to change organizational culture. This transformation occurs at the level of processes and systems. It also affects the people in the institutions, requiring them to continuously update their skills, which is why digital literacy is a prominent topic in empirical studies. This research provides a perspective on digital transformation studies in higher education institutions and their internalization approaches. It may be of value to trainers, students, decisionmakers, and researchers interested in transformation, educommunication, and educational innovation.

Abbreviations WoS: Web of Science; ESCI: Emerging Sources Citation Index

Acknowledgements The authors would like to acknowledge the financial support of Writing Lab, Institute for the Future of Education, Tecnologico de Monterrey, Mexico, in the production of this work.

Authors' contributions Three authors contributed to the content of the article, conceptualizing the approach (Aguaded, Ramirez-Montoya), supporting the study theoretically and methodologically (FariasGaytan, Ramirez-Montoya), and discussing the data (Farias-Gaytan, Aguaded).

Data availability The systematic literature mapping methodology results documented in an Excel database are available at the following address: https://doi.org/10.6084/m9.figshare. 14151563

\section{Declarations}

Competing interests The authors have no relevant financial or non-financial interests to disclose.

Open Access This article is licensed under a Creative Commons Attribution 4.0 International License, which permits use, sharing, adaptation, distribution and reproduction in any medium or format, as long as you give appropriate credit to the original author(s) and the source, provide a link to the Creative Commons licence, and indicate if changes were made. The images or other third party material in this article are included in the article's Creative Commons licence, unless indicated otherwise in a credit line to the material. If material is not included in the article's Creative Commons licence and your intended use is not permitted by statutory regulation or exceeds the permitted use, you will need to obtain permission directly from the copyright holder. To view a copy of this licence, visit http://creativecommons.org/ licenses/by/4.0/. 


\section{References}

Amhag, L., Hellström, L., \& Stigmar, M. (2019). Teacher educators' use of digital tools and needs for digital competence in higher education. Journal of Digital Learning in Teacher Education, 35(4), 203-220. https://doi.org/10.1080/21532974.2019.1646169

Anderson, C., \& Ellerby, W. (2018). Digital maturity model. Achieving digital maturity to drive growth. In Deloitte (Issue February). https:/www2.deloitte.com/content/dam/Deloitte/global/Documents/ Technology-Media-Telecommunications/deloitte-digital-maturity-model.pdf.

Appel, S. (2019). Geospatial information literacy instruction: frameworks, competency, and threshold concepts. Journal of Map \& Geography Libraries, 15(2-3), 134-151. https://doi.org/10.1080/15420 353.2020.1760175

Bates, C. C., Klein, A., Schubert, B., McGee, L., Anderson, N., Dorn, L., \& McClure, E. (2017). E-Books and E-Book Apps: Considerations for beginning readers. Reading Teacher, 70(4), 401-411. https:// doi.org/10.1002/trtr.1543

Blau, I., Shamir-inbal, T., \& Avdiel, O. (2020). How does the pedagogical design of a technologyenhanced, collaborative academic course promote digital literacies, self-regulation, and perceived learning of students? The Internet and Higher Education, 45(December 2019), 100722. https://doi.org/10.1016/j.iheduc.2019.100722

Bond, M., Marín, V. I., Dolch, C., Bedenlier, S., \& Zawacki-Richter, O. (2018). Digital transformation in German higher education: Student and teacher perceptions and usage of digital media. International Journal of Educational Technology in Higher Education, 15(1), 1-20. https://doi.org/ 10.1186/s41239-018-0130-1

Bucea-Manea-Ţoniş, R., Bucea-Manea-Ţoniş, R., Simion, V. E., Ilic, D., Braicu, C., \& Manea, N. (2020). Sustainability in higher education: The relationship between work-life balance and XR e-learning facilities. Sustainability (switzerland), 12(14), 1-19. https://doi.org/10.3390/su121 45872

Colás-Bravo, P., Conde-Jiménez, J., \& Reyes-de Cózar, S. (2017). Competencias digitales del alumnado no universitario. RELATEC Revista Latinoamericana de Tecnología Educativa, 16(1), 7-20. https://doi.org/10.17398/1695-288x.16.1.7

Creswell, J. W. (2014). Research design. Qualitative, quantitative, and mixed methods approaches. In Acta Universitatis Agriculturae et Silviculturae Mendelianae Brunensis (4th ed., Vol. 53, Issue 9). SAGE Publications, Inc.

Cronin, C. (2017). Openness and praxis: Exploring the use of open educational practices in higher education. International Review of Research in Open and Distance Learning, 18(5), 15-34. https://doi.org/10.19173/irrodl.v18i5.3096

Da Silva, S. A. A., \& Cardoso, A. M. P. (2020). Information literacy a systematic literature review. Revista Digital De Biblioteconomia e Ciencia Da Informacao, 18.https://doi.org/10.20396/ RDBCI.V18I0.8660680.

Fucili, E., Masi, A., \& Terranova, D. (2020). El uso de herramientas virtuales en la enseñanza de la historia en la universidad The use of virtual tools in the teaching of history at the university. Virtualidad, Educación y Ciencia, 20(1), 182-191.

García-Peñalvo, F. J. (2017). Mapeos sistemáticos de literatura, revisiones sistemáticas de literatura y benchmarking de programas formativos. Grupo GRIAL, 34(2011), 2011-2014. https://doi.org/ 10.5281/zenodo.399302

González-Pérez, L. I., Ramírez-Montoya, M. S., \& García-Peñalvo, F. J. (2019). Innovación educativa en estudios sobre el desarrollo y uso de la tecnología: un mapeo sistemático. In M. S. Ramírez Montoya \& J. R. Valenzuela González (Eds.), Innovación educativa: tendencias globales de investigación e implicaciones prácticas (Primera, pp. 137-160). Ediciones OCTAEDRO, S. L. https://octaedro.com/libro/innovacion-educativa-tendencias-globales-de-investigacion-e-impli caciones-practicas/.

Guillén-Gámez, F. D., Mayorga-Fernández, M. J., \& Alvarez-Garcia, F. J. (2020). A study on the actual use of digital competence in the practicum of education degree. Technology, Knowledge and Learning, 25(3), 667-684. https://doi.org/10.1007/s10758-018-9390-z

Jackson, N. C. (2019). Managing for competency with innovation change in higher education: Examining the pitfalls and pivots of digital transformation. Business Horizons, 62(6), 761-772. https:// doi.org/10.1016/j.bushor.2019.08.002 
Juergens, C. (2020). Trustworthy COVID-19 mapping: Geospatial data literacy aspects of choropleth maps. KN - Journal of Cartography and Geographic Information, 70(4), 155-161. https://doi. org/10.1007/s42489-020-00057-w

Kane, G. C., Palmer, D., Phillips, A. N., Kiron, D., \& Buckley, N. (2017). Achieving digital maturity. In MIT Sloan Management Review and Deloitte University Press (Issue Summer). http://sloan review.mit.edu/digital2017.

Khan, S. A., \& Bhatti, R. (2017). Digital competencies for developing and managing digital libraries: An investigation from university librarians in Pakistan. Electronic Library, 35(3), 573-597. https://doi.org/10.1108/EL-06-2016-0133

Khitskov, E. A., Veretekhina, S. V., Medvedeva, A. V., Mnatsakanyan, O. L., Shmakova, E. G., \& Kotenev, A. (2017). Digital transformation of society: Problems entering in the digital economy. Eurasian Journal of Analytical Chemistry, 12(5), 855-873. https://doi.org/10.12973/ejac.2017. 00216a

Kitchenham, B. A., \& Charters, S. (2007). Guidelines for performing systematic literature reviews in software engineering. Version 2.3. In IEEJ Transactions on Industry Applications (Vol. 126, Issue 5). https://doi.org/10.1541/ieejias.126.589

Koc, M., \& Barut, E. (2016). Development and validation of New Media Literacy Scale (NMLS) for university students. Computers in Human Behavior, 63, 834-843. https://doi.org/10.1016/j.chb.2016. 06.035

Liu, Z. J., Tretyakova, N., Fedorov, V., \& Kharakhordina, M. (2020). Digital literacy and digital didactics as the basis for new learning models' development. International Journal of Emerging Technologies in Learning, 15(14), 4-18. https://doi.org/10.3991/ijet.v15i14.14669

MacLure, K., \& Stewart, D. (2018). A qualitative case study of e-health and digital literacy experiences of pharmacy staff. Research in Social and Administrative Pharmacy, 14(6), 555-563. https://doi. org/10.1016/j.sapharm.2017.07.001

MendietaBaltodano, CdeM. (2016). Integración en el contexto de la educación superior pública de Nicaragua: El nuevo modelo educativo de la UNAN-Managua. Edmetic, 5(2), 29. https://doi.org/10. 21071/edmetic.v5i2.5775

Miralles-Martínez, P., Gómez-Carrasco, C. J., Arias, V. B., \& Fontal-Merillas, O. (2019). Digital resources and didactic methodology in the initial training of history teachers. Comunicar, 27(61), 41-51. https://doi.org/10.3916/C61-2019-04

Moher, D., Liberati, A., Tetzlaff, J., Altman, D. G., \& Prisma Group. (2009). Preferred reporting items for systematic reviews and meta-analyses: the PRISMA statement. PLoS Medicine, 6(7), 97.

Mongeon, P., \& Paul-Hus, A. (2016). The journal coverage of Web of Science and Scopus: A comparative analysis. Scientometrics, 106(1), 213-228. https://doi.org/10.1007/s11192-015-1765-5

Munoz-Repiso, A., \& del Pozo, M. (2016). Analysis of the digital competences of graduates of university degrees to be a teacher. Revista Latinoamericana de Tecnologia Educativa-RELATEC, 15(2), 155-168. https://doi.org/10.17398/1695-288X.15.2.155

Murray, M. C., \& Pérez, J. (2015). Informing and performing: A study comparing adaptive learning to traditional learning. Informing Science, 18(1), 111-125. https://doi.org/10.28945/2165

NIH Office of Behavioral and Social Sciences Research. (2018). Best practices for mixed methods research in the health sciences (2nd ed) (NIH (ed.); 2nd ed.). National Institutes of Health. https:// www.obssr.od.nih.gov/wp-content/uploads/2018/01/Best-Practices-for-Mixed-Methods-Researchin-the-Health-Sciences-2018-01-25.pdf.

Önger, S., \& Çetin, T. (2018). An investigation into digital literacy views of social studies preservice teachers in the context of authentic learning. Review of International Geographical Education Online, 8(1), 109-124.

Osmundsen, K. (2020). Competencies for Digital Transformation: Insights from the Norwegian Energy Sector. Proceedings of the 53rd Hawaii International Conference on System Sciences, January. https://doi.org/10.24251/hicss.2020.529

Pihir, I., Tomičić-Pupek, K., \& Furjan, M. T. (2019). Digital transformation playground - literature review and framework of concepts. Journal of Information and Organizational Sciences, 43(1), 33-48. https://doi.org/10.31341/jios.43.1.3

Poncette, A.-S., Spies, C., Mosch, L., Schieler, M., Weber-Carstens, S., Krampe, H., \& Balzer, F. (2019). Clinical requirements of future patient monitoring in the intensive care unit: Qualitative study. JMIR Medical Informatics, 7(2), e13064. https://doi.org/10.2196/13064

Ramírez-Montoya, M.-S., \& Lugo-Ocando, J. (2020). Revisión sistemática de métodos mixtos en el marco de la innovación educativa. Comunicar, 28(65), 9-20. https://doi.org/10.3916/C65-2020-01 
Rampelt, F., Orr, D., \& Knoth, A. (2019). Bologna Digital 2020 Education. White Paper on Digitalisation in the European Higher Education Area (Issue May 2019). Hochschulforum Digitalisierung.

Reyna, J., \& Meier, P. (2018). Using the Learner-Generated Digital Media (LGDM) framework in tertiary science education: A pilot study. Education Sciences, 8(3). https://doi.org/10.3390/educsci8030106

Salmieri, L. (2019). The rhetoric of digitalization in Italian educational policies: Situating reception among digitally skilled teachers. Italian Journal of Sociology of Education, 11(1), 162-183. https:// doi.org/10.14658/pupj-ijse-2019-1-8

Sánchez, A. C., Romero, C. S., \& Hernández, J. F. C. (2017). New techno-pedagogical models: Digital competence in university students. Revista Electronica de Investigacion Educativa, 19(1), 1-9. https://doi.org/10.24320/redie.2017.19.1.1148

Schallmo, D., Williams, C. A., \& Boardman, L. (2017). Digital transformation of business models-best practice, enablers, and roadmap. International Journal of Innovation Management, 21(8), 1-17. https://doi.org/10.1142/S136391961740014X

Sjöberg, J., \& Lilja, P. (2019). University teachers' ambivalence about the digital transformation of higher education. International Journal of Learning, Teaching and Educational Research, 18(13), 133149. https://doi.org/10.26803/ijlter.18.13.7

Suwana, F., \& Lily. (2017). Empowering Indonesian women through building digital media literacy. Kasetsart Journal of Social Sciences, 38(3), 212-217. https://doi.org/10.1016/j.kjss.2016.10.004

Ting, Y. L. (2015). Tapping into students' digital literacy and designing negotiated learning to promote learner autonomy. Internet and Higher Education, 26, 25-32. https://doi.org/10.1016/j.iheduc.2015. 04.004

Tømte, C., Enochsson, A. B., Buskqvist, U., \& Kårstein, A. (2015). Educating online student teachers to master professional digital competence: The TPACK-framework goes online. Computers and Education, 84, 26-35. https://doi.org/10.1016/j.compedu.2015.01.005

Torres-Coronas, T., \& Vidal-Blasco, M. A. (2015). Percepción de estudiantes y empleadores sobre el desarrollo de competencias digitales en la educación superior. Revista De Educacion, 367, 63-89. https://doi.org/10.4438/1988-592X-RE-2015-367-283

UNESCO. (2017). Working group on education: Digital skills for life and work. In Broadband commission for sustainable development.

Vasilev, V., Kazan, F. U., Gapsalamov, A., Kazan, F. U., Akhmetshin, E., Bochkareva, T. N., Yumashev, A. V., \& Anisimova, T. I. (2020). Digitalization peculiarities of organizations: A case study. Entrepreneurship and Sustainability Issues, 7(4), 3173-3190. https://doi.org/10.9770/jesi.2020.7.4(39)

Vial, G. (2019). Understanding digital transformation: A review and a research agenda. Journal of Strategic Information Systems, 28(2), 118-144. https://doi.org/10.1016/j.jsis.2019.01.003

Villarreal-Villa, S., García-Guliany, J., Hernández-Palma, H., \& Steffens-Sanabria, E. (2019). Teacher competences and transformations in education in the digital age. Formacion Universitaria, 12(6), 3-14. https://doi.org/10.4067/S0718-50062019000600003

Wang, L., Feng, P., \& Chen, J. (2017). Pre-service teachers' development of digital literacies: A case study in a Wiki-based collaborative writing context. International Journal of Computer-Assisted Language Learning and Teaching, 7(3), 21-29. https://doi.org/10.4018/IJCALLT.2017070102

Wanotayapitak, S., Saraubon, K., \& Nilsook, P. (2019). Process design of cooperative education management system by cloud-based blockchain E-Portfolio. International Journal of Online and Biomedical Engineering, 15(8), 4-17. https://doi.org/10.3991/ijoe.v15i08.10374

Xiao, J. (2020). Digital transformation in higher education: Critiquing the five-year development plans (2016-2020) of 75 Chinese universities. Distance Education, 40(4), 515-533. https://doi.org/10. $1080 / 01587919.2019 .1680272$

Publisher's note Springer Nature remains neutral with regard to jurisdictional claims in published maps and institutional affiliations. 


\section{Authors and Affiliations}

\section{Silvia Farias-Gaytan ${ }^{1}(1) \cdot$ Ignacio Aguaded ${ }^{2}(10$.} Maria-Soledad Ramirez-Montoya ${ }^{3}$ (])

Ignacio Aguaded

aguaded@uhu.es

Maria-Soledad Ramirez-Montoya

solramirez@tec.mx

1 Educational Innovation Division, Tecnologico de Monterrey, Monterrey, NL, Mexico

2 Education Department, University of Huelva, Huelva, Andalucia, Spain

3 Humanities and Education School, Tecnologico de Monterrey, Monterrey, NL, Mexico 